Bangladesh J. Bot. 42(1): 83-90, 2013 (June)

\title{
EFFECTS OF SALICYLIC ACID ON SUCROSE SYNTHASE ACTIVITY DURING SEED DEVELOPMENT AND GERMINATION IN PEA (PISUM SATIVUM L.)
}

\author{
Ghulam Murtaza* and Rehana Asghar ${ }^{1}$ \\ Department of Botany, City Campus, University of Azad Jammu and Kashmir, \\ Muzaffarabad, Pakistan
}

Key words: Pisum sativum, Pea, Salicylic acid, Sucrose synthase, Seed development, Germination

\begin{abstract}
Effects of 0, 0.1 and $0.01 \mathrm{mM}$ salicylic acid (SA) on activities of sucrose synthase (Sus) in four varieties of pea (Pisum sativum L.) viz., Meteor, Climax, Green feast and Rondo during seed development and germination were studied. Sus activity was highest in the variety Meteor and for the varieties treated with SA $(0.1 \mathrm{mM})$, while the varieties treated twice i.e. seed treated plus foliar spray revealed maximum Sus activity. During germination, the maximum Sus activity was observed for the variety Green feast. Seeds treated with SA $0.1 \mathrm{mM}$ revealed maximum Sus activity, while the seeds raised from the varieties and whose seeds were treated plus foliar sprayed exhibited maximum Sus activity.
\end{abstract}

\section{Introduction}

Salicylic acid (SA) is a ubiquitous phenolic compound occurring in plants in very low amounts and has been reported to regulate the physiological processes in plants such as nutrient uptake, stomatal closure, inhibition of ethylene biosynthesis, chlorophyll synthesis, protein synthesis, photosynthesis and transpiration (Khan et al. 2003, Raskin 1992, Shakirova et al. 2003). The expression of pathogenesis related protein genes has been regulated by SA, suggesting its key role as a signal molecule by providing resistance against pathogen attack (Raskin 1992). The application of salicylic acid revealed an increase in number of pods and yield in mung bean (Sing and Kaur 1980).

The developing seed is a sucrose sink on the intact plant and during germination it becomes a source plus a sink as the cotyledons produce sucrose and the young embryonic plant consumes sucrose. The sucrose synthase (Sus) is a key enzyme of metabolism of carbohydrate in all the plant species. Sus is thought to be responsible for the mobilization of sucrose in sink organs including pea embryos, and to be determinant of sink strength in these organs (Zrenner et al. 1995, Edwards and Rees 1986a,b). Sus is implicated in a wide variety of processes, including starch synthesis (Ricard et al. 1998) and phloem transport (Geigenberger et al. 1993). The activity of Sus in pea testa is proposed to help the interconversion of sucrose and starch and thus buffering supply of carbohydrates to the immature embryo (Rochat and Boutin 1992). The present study was undertaken to examine the effects of SA on the activity of Sus during seed development and germination in pea.

\section{Materials and Methods}

The field experiments were carried out during the growing seasons of 2003 and 2005 at Vegetable Seed Production Farm, Chattar Klas, Muzaffarabad, Azad Kashmir, Pakistan. Four varieties of pea (Pisum sativum L.) i.e. Meteor, Climax, Green feast and Rondo were obtained

*Author for correspondence. <gmurtazaq@hotmail.com>. ${ }^{1}$ Department of Biotechnology, Mirpur University of Science and Technology (MUST), Mirpur, Azad Kashmir, Pakistan. 
from Ayub Agricultural Research Institute (AARI), Faisalabad. The crops were planted in splitsplit plot fashion with three replicates. The main plots were assigned to pea cultivars, with salicylic acid (0, 0.1 and $0.01 \mathrm{mM}$ in water) as subplots and modes of application of salicylic acid (seed treatment, seed treatment plus foliar spray and foliar spray only) as sub-sub-plots. The soil was silt loam with pH 7.2. After thoroughly preparing, the soil was added with N: P: K @ 45: 90: $90 \mathrm{~kg} / \mathrm{ha}$ as urea, single super phosphate (SSP) and sulphate of potash (SOP). Half of the amount of urea was added at soil preparation and other half at 45 days after germination. The main plot was divided into subplots and sub-subplots. Each sub-subplot measured $3 \times 1.8 \mathrm{~m}^{2}\left(5.4 \mathrm{~m}^{2}\right)$ with plant to plant distance $15 \mathrm{~cm}$ and row to row distance $90 \mathrm{~cm}$ (Hussain and Badshah 2002). There were two rows in each sub-subplot and 20 plants in each row. Weeding, hoeing and other agronomic practices were carried out uniformly as and when needed. For germination experiments, the seeds obtained from the crop were sown in plastic trays filled with the same soil that was used for growing the crop in the field. The germination experiments and the enzyme assays and protein estimations were carried out in the Department of Botany, University of Azad Jammu and Kashmir, Muzaffarabad, Pakistan.

Salicylic acid treatment and sampling: Salicylic acid (Sigma) (MW 138.1) was dissolved in a few drops of dimethylsulfoxide and added to a ultimate volume one liter of distilled water. The $\mathrm{pH}$ was adjusted at 5.5 with $\mathrm{KOH}(1.0 \mathrm{~N})$. Three concentrations of SA $(0,0.1$ and $0.01 \mathrm{mM})$ were maintained. The seeds were soaked in SA concentrations for six hours. The plants were sprayed at phenological stage after Biologische Bundesanstalt, Bundesortenamt and Chemical Industry, BBCH 60 (first flower open sporadically within the population) with aqueous solutions SA concentrations during early morning when the 3rd leaf of the plants completely expanded. In all cases spraying were carried out using a manual pump (Gutierrez-Coronado et al. 1998). Pods were sampled at three different phenological growth stages i.e. BBCH zero (germination), BBCH 7 (fruit development) and BBCH 8 (ripening of fruit and seed), respectively (Feller et al. 1995, Weber and Bleiholder 1990). For BBCH 7 and 8, the pods were collected at BBCH 73 (30 per cent of pods reached average maximum length), BBCH 77 (70 per cent of pods reached average maximum length), BBCH 83 (30 per cent of pods were ripe, dry and hard) and BBCH 88 (80 per cent of pods ripe, dry and hard). The seeds obtained from the crop were used for germination experiment. The seeds were surface sterilized (70 per cent ethanol for 1 minute and 5 per cent sodium hypochlorite for 5 minutes) and thoroughly rinsed with distilled water. For phenological growth stage zero, the samples were collected at BBCH 01 (beginning of seed imbibition), at $\mathrm{BBCH} 03$ (seed imbibition complete) and at $\mathrm{BBCH} 05$ (radicle emergence from the seed). All samples were stored at $-50^{\circ} \mathrm{C}$ in a deep freezer.

Sucrose synthase extraction and assays: Sucrose synthase was extracted using the method of Rochat and Boutin (1992). Sus activity was assayed for sucrose cleavage by monitoring the synthesis of UDP-glucose following the method of Weber et al. (1996). Protein content was determined according to Bradford (1976) with BSA as a standard.

\section{Results and Discussion}

A statistically significant difference $(\mathrm{p}<0.001)$ was found among varieties in terms of Sus activity at all the four phenological stages (Table 1, Fig. 1). Over all, the varieties revealed highest activity of Sus at BBCH 73 in the both seasons, whereas, the lowest Sus activity was recorded for all the varieties at BBCH 88. The highest Sus activity was observed for the variety Meteor and the lowest Sus for the variety Green feast in both the seasons.

The effect of SA concentrations on Sus activity was significant $(\mathrm{p}<0.001)$ at all the four phenological stages during both seasons (Table 1, Fig. 2). The maximum Sus activity was 
recorded for the plants treated with $0.1 \mathrm{mM} \mathrm{SA}$ at all the four stages. The interaction between SA and varieties was non-significant.

The modes of application of SA were significantly different in terms of Sus activities at all the four phenological stages (Table 1, Fig. 3). The maximum Sus activity was recorded for the plants whose seeds were treated plus foliar application applied followed by the plants treated with foliar application and the least Sus activity for the plants whose seeds were treated only. A significant interaction ( $p>0.001$ ) between varieties and modes of application was recorded at BBCH 73 in both the seasons, while at BBCH 73 and BBCH 77 the interaction was significant in 2004-2005

Table 1. Mean squares from the analyses of variance and coefficient of variation (CV) of activities of Sus ( $\mu$ mol $\mathrm{min} / \mathrm{mg} /$ protein) in pea varieties treated with salicylic acid by different modes of application at different phenological stages.

\begin{tabular}{|c|c|c|c|c|c|c|c|c|c|}
\hline \multirow{3}{*}{$\begin{array}{l}\text { Source of } \\
\text { variation }\end{array}$} & \multirow{3}{*}{ Df } & \multicolumn{8}{|c|}{ Phenological stage } \\
\hline & & \multicolumn{2}{|c|}{ BBCH 73} & \multicolumn{2}{|c|}{ BBCH 77} & \multicolumn{2}{|c|}{ BBCH 83} & \multicolumn{2}{|c|}{ ВBCH 88} \\
\hline & & 2003-'04 & 2004-'05 & 2003-'04 & 2004-'05 & 2003-'04 & 2004-'05 & 2003-'04 & 2004-'05 \\
\hline Replications & 2 & 1.70 & 3.46 & $10.33^{*}$ & 0.95 & 3.55 & 5.41 & 1.24 & $12.76^{* *}$ \\
\hline Varieties (V) & 3 & $76.20^{* * *}$ & $198.59^{* * *}$ & $69.26^{* * *}$ & $47.10^{* * *}$ & $55.44^{* * *}$ & $100.07^{* * *}$ & $58.85^{* * *}$ & $102.42^{* * *}$ \\
\hline Error a & 6 & 2.60 & 4.13 & 1.25 & 1.35 & 1.92 & 3.89 & 2.19 & 1.14 \\
\hline Salicylic acid (S) & 2 & $60.02^{* * *}$ & $68.25^{* * *}$ & $65.99^{* * *}$ & $52.89^{* * *}$ & $81.89^{* * *}$ & $39.81^{* * *}$ & $39.54^{* * *}$ & $29.05^{* * *}$ \\
\hline $\mathrm{V} \times \mathrm{S}$ & 6 & $2.83^{*}$ & 4.39 & 0.99 & 0.59 & 2.10 & 1.77 & 2.18 & 3.52 \\
\hline Error b & 16 & 1.01 & 3.00 & 1.32 & 0.35 & 1.51 & 1.57 & 1.27 & 1.31 \\
\hline Mode (M) & 2 & $179.68^{* * *}$ & $215.29^{* * *}$ & $69.86^{* * *}$ & $90.73^{* * *}$ & $38.84^{* * *}$ & $53.75^{* * *}$ & $38.76^{* * *}$ & $60.45^{* * *}$ \\
\hline $\mathrm{V} \times \mathrm{M}$ & 6 & $4.12^{* * *}$ & $6.68^{* * *}$ & 0.25 & $0.65^{*}$ & $0.55^{* *}$ & 0.15 & 0.20 & 0.18 \\
\hline $\mathrm{S} \times \mathrm{M}$ & 4 & $4.52^{* * *}$ & $6.35^{* *}$ & 0.02 & $0.93^{*}$ & $0.66^{* *}$ & $0.56^{*}$ & 0.19 & 0.53 \\
\hline $\mathrm{V} \times \mathrm{S} \times \mathrm{M}$ & 12 & 0.79 & 1.17 & 0.20 & 0.19 & 0.24 & 0.20 & 0.10 & 0.36 \\
\hline Error c & 48 & 0.42 & 1.42 & 0.13 & 0.27 & 0.13 & 0.16 & 0.14 & 0.19 \\
\hline $\mathrm{CV}$ & & 4.46 & 7.93 & 2.52 & 3.69 & 3.11 & 3.45 & 4.63 & 4.56 \\
\hline
\end{tabular}

$*, * *, * * *$ Significant at $\mathrm{p}=0.05,0.01$ and 0.001 , respectively.

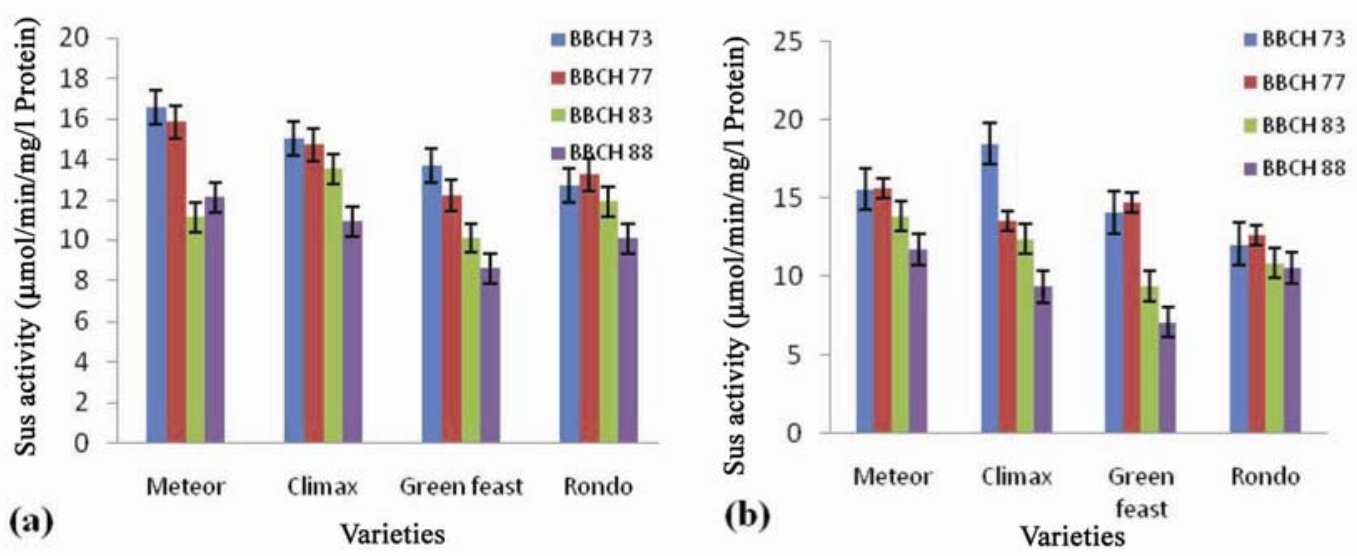

Fig. 1. Effect of SA on the activity of sucrose synthase in pea varieties at four phenological stages in 20032004 (a) and 2004-2005 (b). The means of three replicates are shown and standard errors are indicated.

and 2003-2004, respectively in terms of Sus activity. At all the remaining phenological stages, the interaction between varieties and modes of application was nonsignificant. A significant interaction was also recorded between SA concentrations and modes of application at BBCH 73, 
BBCH 77 and BBCH 83, while it was found nonsignificant at BBCH 88. The interaction between varieties, SA concentrations and modes of applications were statistically nonsignificant.
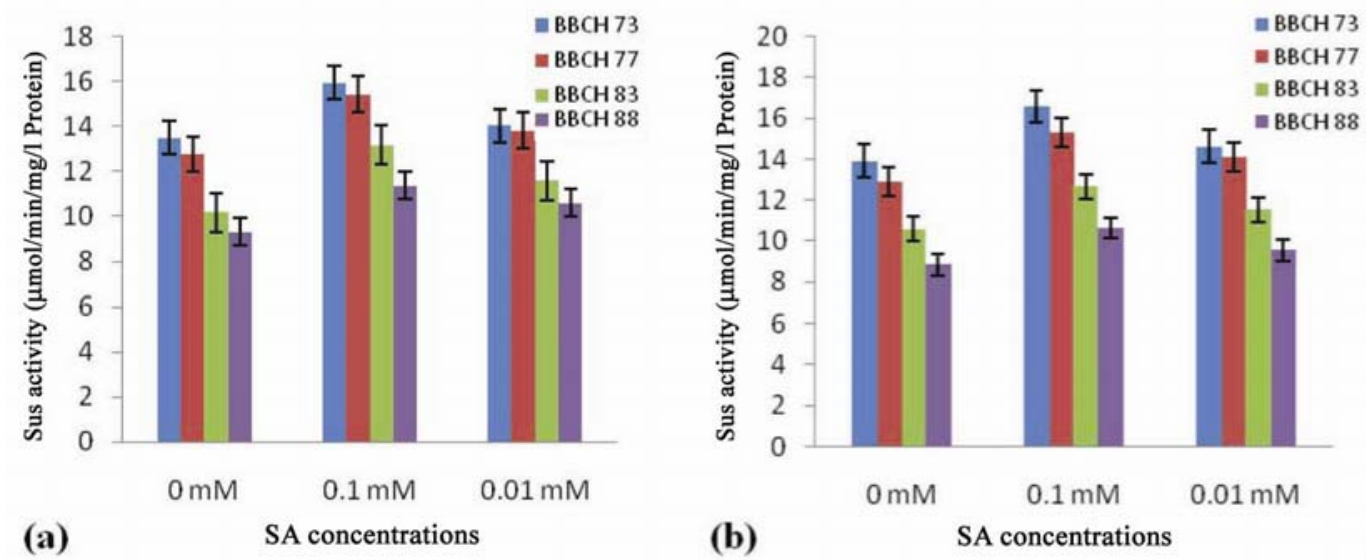

Fig. 2. Effect of salicylic acid (SA) concentrations on the activity of sucrose synthase in pea at four phenological stages in 2003-2004 (a) and 2004-2005 (b). ( $n=3)$.
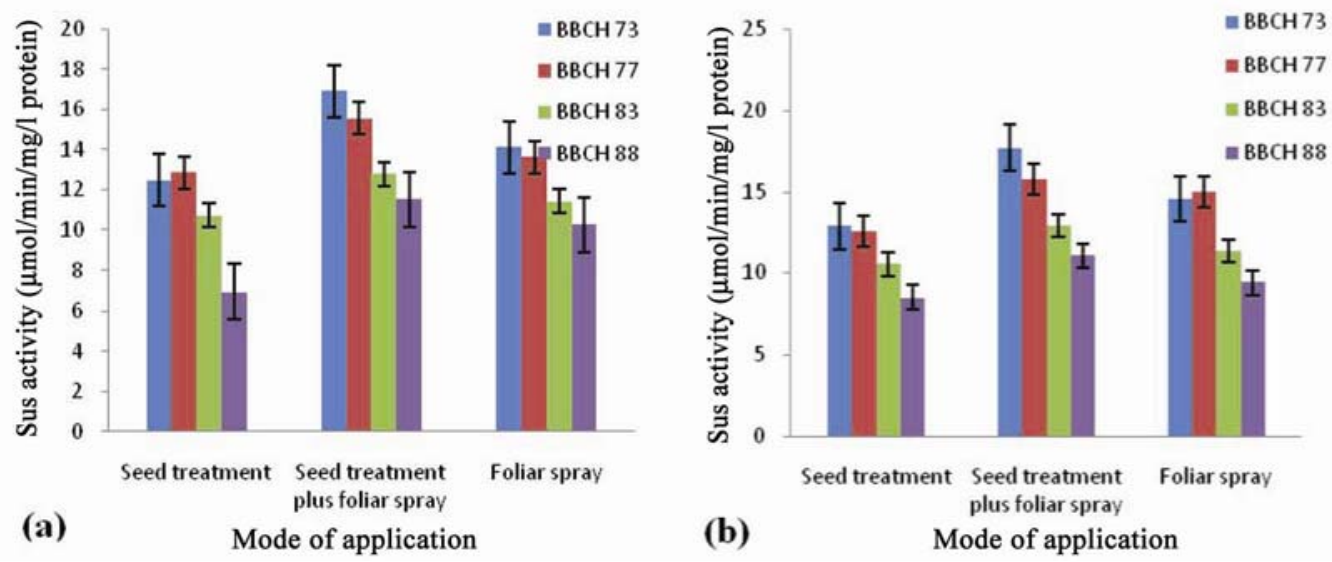

Fig. 3. Effect of modes of application of SA on the activity of sucrose synthase in pea at four phenological stages in 2003-2004 (a) and 2004-2005 (b). $(n=3)$.

The changes in the activities of Sus induced by SA were observed at phenological stages BBCH 01, BBCH 03 and BBCH 05 in 2003-04 and 2004-05. A significant difference was recorded among the four pea varieties ( $p>0.001$ ) in both the years (Table 2, Fig. 4). Maximum Sus activity was observed for the variety Green feast at all three phenological growth stages during both growing seasons.

The effect of SA concentrations was significant $(p>0.001)$ in terms of Sus activity at all the three phenological stages in both the seasons (Table 2, Fig. 5). The maximum Sus activity was recorded for the plants treated with SA concentration $0.01 \mathrm{mM}$. The interaction between varieties and SA concentrations was found nonsignificant. 
Table 2. Mean squares from the analyses of variance and coefficient of variation (CV) of the activities of Sus ( $\mu$ mol $\mathrm{min} / \mathrm{mg} / \mathrm{protein})$ in pea varieties treated with salicylic acid (SA) concentrations by different modes of application during year 2003-2004 and 2004-2005 at phenological stages.

\begin{tabular}{llllllll}
\hline \multirow{2}{*}{$\begin{array}{l}\text { Source of } \\
\text { variation }\end{array}$} & \multirow{2}{*}{ Df } & \multicolumn{3}{c}{ BBCH 01 } & \multicolumn{2}{c}{ BBCH 03 } & \multicolumn{2}{c}{ BBCH 05 } \\
\cline { 3 - 8 } & & $2003-2004$ & $2004-2005$ & $2003-2004$ & $2004-2005$ & $2003-2004$ & $2004-2005$ \\
\hline Replication & 2 & 0.12 & 0.01 & 0.98 & 0.28 & 2.46 & 3.02 \\
Variety & 3 & $6.47^{* * *}$ & $7.76^{* * *}$ & $100.76^{* *}$ & $243.37^{* * *}$ & $277.56^{* *}$ & $214.15^{* * *}$ \\
Error a & 6 & 0.22 & 0.25 & 4.98 & 3.00 & 12.76 & 6.72 \\
Salicylic acid & 2 & $5.29^{* * *}$ & $3.37^{* * *}$ & $45.27^{* * *}$ & $71.88^{* * *}$ & $52.27^{* * *}$ & $261.83^{* * *}$ \\
V $\times$ S & 6 & 0.04 & 0.17 & 3.17 & 2.03 & 11.37 & 2.91 \\
Error b & 16 & 0.12 & 0.17 & 1.99 & 2.03 & 4.60 & 2.91 \\
Mode & 2 & $9.60^{* * *}$ & $12.44^{* * *}$ & $104.69^{* * *}$ & $145.54^{* * *}$ & $252.88^{* * *}$ & $235.71^{* * *}$ \\
V $\times$ M & 6 & 0.12 & 0.10 & 0.58 & 0.21 & $3.18^{*}$ & 1.11 \\
S $\times$ M & 4 & $0.18^{*}$ & $0.44^{* *}$ & 0.92 & 0.35 & 0.18 & 0.36 \\
V $\times$ S $\times$ M & 12 & 0.05 & 0.07 & 0.63 & 0.86 & 1.52 & 0.54 \\
Error c & 48 & 0.07 & 0.09 & 0.99 & 0.44 & 1.13 & 0.67 \\
CV & & 10.67 & 9.74 & 14.24 & 7.16 & 10.77 & 7.42 \\
\hline
\end{tabular}

*, **, *** Significant at $\mathrm{p}=0.05,0.01$ and 0.001 , respectively. BBCH 01 (beginning of seed imbibition), BBCH 03 (seed imbibition complete) and BBCH 05 (radicle emerged from seed).
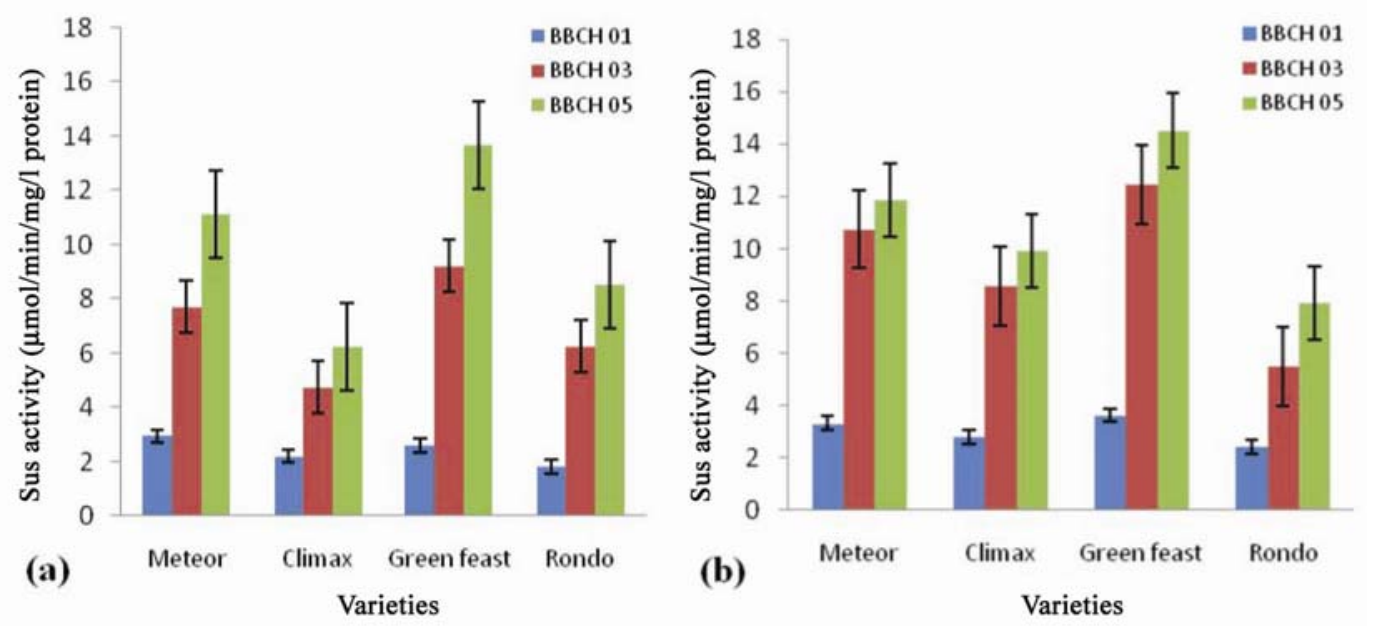

Fig. 4. Changes in activities of sucrose synthase in the seeds raised from SA treated pea varieties in 20032004 (a) and 2004-2005 (b) at three phonological stages. $(n=3)$.

There was a statistical difference between modes of application of SA regarding Sus activity (p > 0.001) at BBCH 01, BBCH 03 and BBCH 05 in 2003-04 and 2004-05 (Table 2, Fig. 6). Highest Sus activity was recorded for the plants whose seeds were treated plus leaf sprayed followed by that of the foliar sprayed. A nonsignificant interaction between varieties and modes of application was recorded. A significant interaction between SA and modes of application was recorded during both growing seasons at $\mathrm{BBCH}$ 01, while it was nonsignificant at $\mathrm{BBCH} 03$ and $\mathrm{BBCH}$ 05. Interaction between varieties, SA concentrations and modes of application was statistically nonsignificant. 
In the present study, the seeds of the variety Meteor showed the highest activity of Sus as compared to all other varieties. Sus activities were higher at the phenological stages BBCH 73 and BBCH 77, while it declined gradually toward the phenological stages BBCH 83 and BBCH 88 (Fig. 1). Furthermore, Sus activities were higher in the plants treated with SA concentration 0.1 $\mathrm{mM}$ as compared with $0 \mathrm{mM}$ and with the plants treated with SA concentration $0.01 \mathrm{mM}$ (Fig. 2).

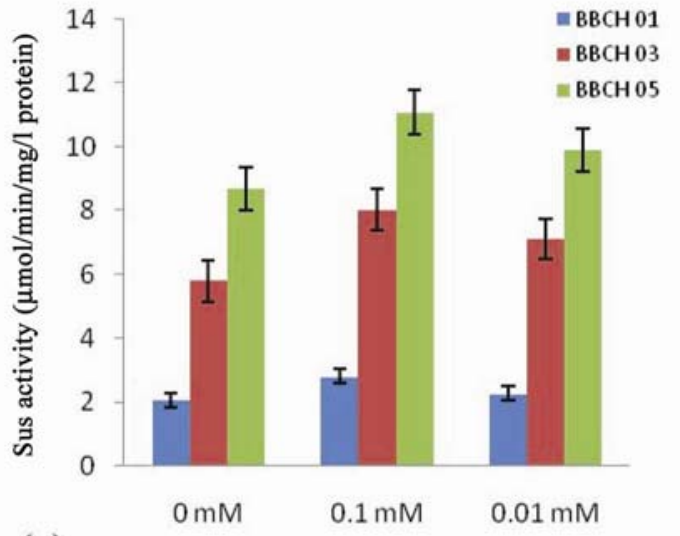

(a)

SA concentration

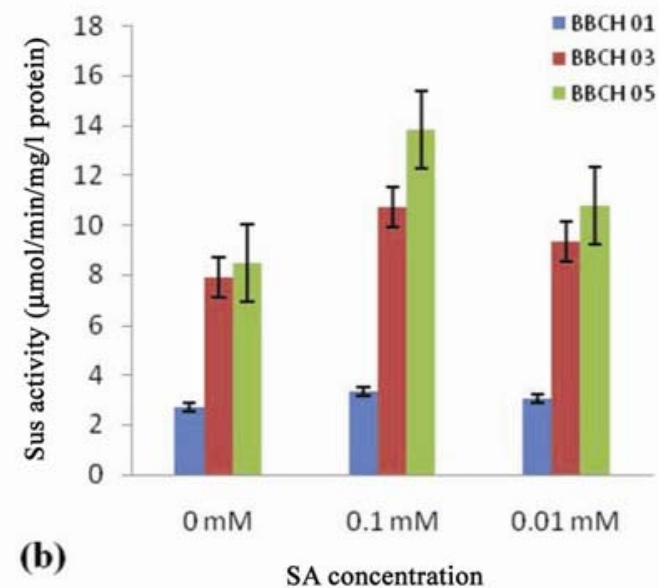

Fig. 5. Effect of different SA concentrations on the activity of sucrose synthase at three phenological stages in 2003-04 (a) and 2004-05 (b). $(n=3)$.
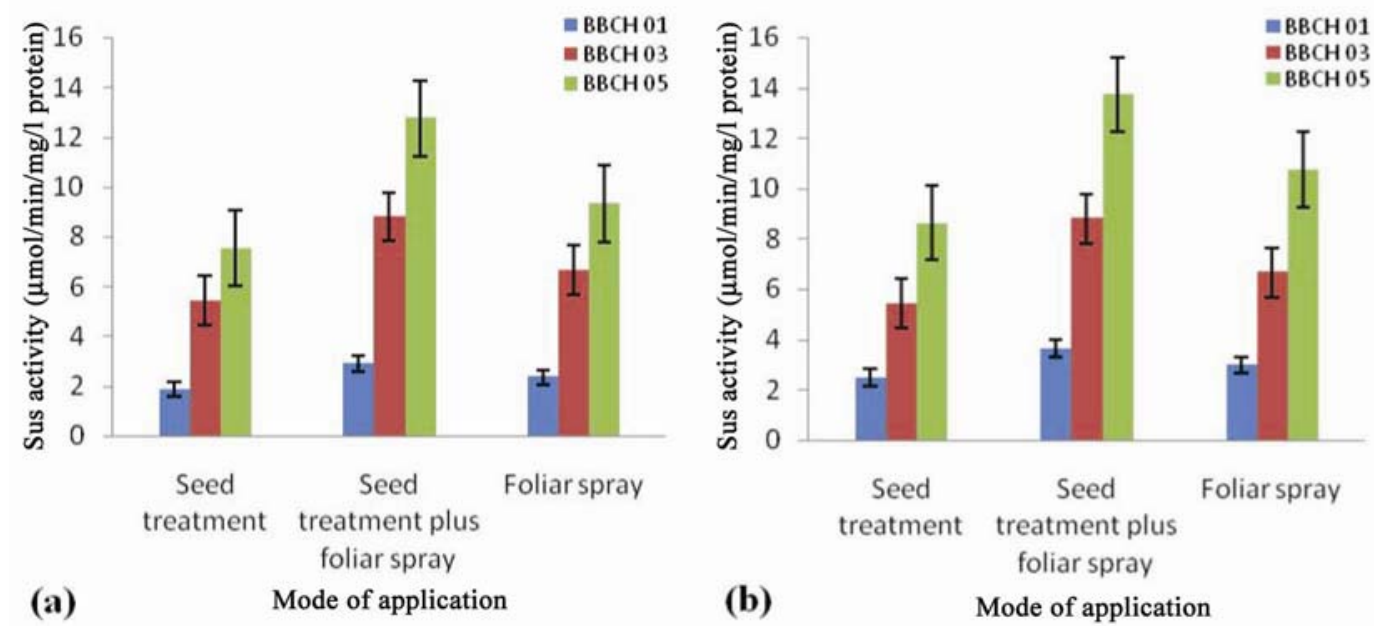

Fig. 6. Effect of different modes of applications of SA on the activity of sucrose synthase in pea during 200304 (a) and 2004-05 (b). The means of three replicates are shown and standard errors are indicated.

The higher activities of Sus at phenological stages BBCH 73, BBCH 77 and BBCH 83 indicated that main metabolic activity of pea seed was devoted to the biosynthesis of starch from the phloem derived sucrose resulted in active storage of starch in the cotyledons. The sequentional development of pea seed required that sink size was more or less fixed before storage takes place (Ambrose et al. 1987). During the present study the higher rate of Sus clearly reflected the activity 
of sink as was suggested by Ho (1988). Comparatively low Sus activity at the phenological stage BBCH 88 can be correlated with the reduction in uploading of phloem assimilates. The activity of Sus is positively correlated with the starch synthesis.

Sucrose is the most important primary nutrient essentially for all the higher plant cells. When sucrose is broken down by sucrose synthase pathway, both hexoses from sucrose can feed into glycolysis. In the present study, there was a gradual increase in Sus activities starting from the phenological stage BBCH 01 to the phenological stage BBCH 05 in all the four varieties (Fig. 4). The maximum Sus activity was observed for the variety Green feast while Rondo exhibited the lowest Sus activity at all the three stages of germination. The increase in Sus activity may be due to increasing demand for cellulose synthesis and preparation for the nodulation at the later stages of seed germination. The activities of Sus were also higher in the seed raised from pea plants treated with SA concentration $0.1 \mathrm{mM}$ and seeds raised from seed treated plus foliar sprayed (STFS) plants. Over all, the Sus activity was induced by SA and this induction was more distinct in the pea plants that received two doses of SA as seed treatment plus foliar spray. The results of the present study are in general agreement with earlier studies (Dejardin et al. 1997, Ambrose et al. 1988, Ho 1988).

\section{References}

Ambrose MJ, Wang TL, Cook SK and Hedley CL 1987. An analysis of seed development in Pisum sativum. IV. Cotyledon cell populations in vivo and in vitro. J. Exp. Bot. 38: 1909-1920.

Bradford M 1976. A rapid and sensitive method for the quantitation of microgram quantities of proteins utilizing the principle of protein dye-binding. Anal. Biochem. 72:248-254.

Dejardin A, Rochat C, Maugenest S and Boutin JP 1997. Purification, characterization and physiological role of sucrose synthase in pea seed coat (Pisum sativum L.). Planta 201: 128-137.

Edwards J and Rees TA 1986a. Sucrose partitioning in developing embryos of round and wrinkled varieties of Pisum sativum. Phytochemistry 25: 2027-2032.

Edwards J and Rees TA 1986b. Metabolism of UDPglucose by developing embryos of round and wrinkled varieties of Pisum sativum. Phytochemistry 25: 2033-2039.

Feller C, Nleiholder HB, Buhr L, Hack H, Hess M, Klose R, Meier U, Status R, Van Den Boom T and Weber E 1995. Phänologische Entwicklungsstadien von Gemüsepflanzen: I. Fruchtgemüse und Hulsenfrüchte. Nachrichtenbl. Deut. Pflanzenschutzd. 47: 217-232.

Geigenberger P, Langenberger S, Wilke I, Heineke D, Heldt HW and Stitt M 1993. Sucrose is metabolised by sucrose synthase and glycolysis within the phloem complex of Ricinus communis L. seedlings. Planta 190: 446-453.

Gutierrez-Coronado MA, Trejo-Lopez C and Larque-Saavedra A 1998. Effects of salicylic acid on the growth of roots and shoots in soybean,. Plant Physiol. Biochem. 36(8): 563-565.

Ho LC 1988. Metabolism and compartmentation of imported sugars in sink organs in relation to sink strength. Annu. Rev. Plant Physiol. 39: 355-378.

Hussain SA and Badshah N 2002. Study on the adaptive behaviour of exotic pea (Pisum sativum L.) varieties under local conditions of Peshawar. Asian J. Plant Sci. 1(5): 567-568.

Khan W, Prithiviraj B and Smith DL 2003. Photosynthetic responses of corn and soybean to foliar application of salicylates. J. Plant Physiol. 160: 485-492.

Raskin I 1992. Role of salicylic acid in plants. Ann. Rev. Plant Physiol. Mol. Biol. 43: 39-463.

Ricard B, Toai TV, Chourey P and Saglio P 1998. Evidence for the critical role of sucrose synthase for anoxic tolerance of maize roots using a double mutant. Plant Physiol. 116: 1323-1331.

Rochat C and Boutin JP 1992. Temporary storage compounds and sucrose starch metabolism in seed coats during pea seed development. Plant Physiol. 85: 567-572. 
Shakirova FM, Sakhabutdinova AR, Bezrukova MV, Fatkhutdinova RA and Fatkhutdinova DR 2003. Changes in the hormonal status of wheat seedlings induced by salicylic acid and salinity. Plant Sci. 164: 317-322.

Sing G and Kaur M 1980. Effect of growth regulators on podding and yield of mung beans (Vigna radiata (L.) Wilczek). Indian J. Plant Physiol. 23: 366-370.

Weber E and Bleiholder H 1990. Erläuterungen zu den BBCH-Dezimal-Codes für die Entwicklungsstadien von Mais, Raps, Faba-Bohne, Sonnenblume und Erbse-mit Abbildungen. Gesunde Pflanzen. 42: 308321.

Weber H, Buchner P, Borisjuk L and Wobus U 1996. Sucrose metabolism during cotyledon development of Vicia faba L. is controlled by the concerted action of both sucrose-phosphate synthase and sucrose synthase: expression patterns, metabolic regulation and implications for seed development. Plant J. 9(6): 841-850.

Zrenner R, Salanoubat M, Willmitzer L and Sonnewald U 1995. Evidence of crucial role of sucrose synthase for sink strengtrh using transgenic potatoplants (Solanum tuberosum L.). Plant J. 7: 97-1007.

(Manuscript received on 18 January, 2012; revised on 13 October, 2012) 